\title{
THE CREATION OF THE MODEL THRESHOLD TOURIST AREA LIFE CYCLE OF THE FUNCTIONAL URBAN AREA OF KOŁOBRZEG
}

\author{
MARIUSZ MIEDZIŃSKI \\ Pomeranian University in Słupsk, POLAND \\ e-mail: miedzinski.m@interia.pl
}

\begin{abstract}
\begin{tabular}{l|l} 
KEYWORDS & Kołobrzeg, functional urban area, threshold theory, tourist area life cycle, threshold tourist area life
\end{tabular} cycle

$\begin{array}{lll}\text { ABSTRACT } & \text { This research will attempt to modify the Tourist Area Life Cycle (TALC) previously developed by }\end{array}$ R.W. Butler. The author of the modified TALC introduces the premises of the Threshold Theory by B. Malisz, based on the research of Kozłowski. The effect is creating a model of the Threshold Tourist Area Life Cycle (TTALC). The theoretical model and its course were then tested on the basis of the Functional Urban Area of Kołobrzeg known as FUA. This is one of the most developed types of Polish tourist regions. To confirm its development, threshold crossings identified the thresholds supported by the development of technical infrastructure, accommodation facilities, the number and size of the usable area of the housing, as well as "second houses" and "second apartments" (houses/ apartments in addition to permanent dwellings). The purpose of the study is to test TTALC based on the selected tourist destinations included in the FUA, including the health resorts of Kołobrzeg.
\end{abstract}

\section{Introduction}

In accordance with the provisions of the document "National Spatial Development Concept 2030", Kołobrzeg is an important urban center on which the FUA can be created. In February 2014, the document "Strategy for the Development of the Functional Coastal Area" was accepted, and at the turn of the year of 2014/2015 other concepts were developed which included: the natural 
valuation of FUA, a uniform identification system for FUA, and the FUA transport policy. ${ }^{1}$ The high level of integration and the functional connection justifies establishing the FUA as the leading feature in the spa and leisure tourism. Complex developmental processes occurring in the area due to the very strong development of accommodation facilities, communication infrastructure, and associated services, point to the need to address the problems of the entire TALC FUA. The aim of this article is to analyze the modified course of TALC, provide an introduction to the principles of the Threshold Theory by B. Malisz, reconstruct TALC into TTALC, and provide evidence of the TTALC application run on selected examples of tourist sites of the FUA. TTALC may be another modification or reconstruction of TALC while maintaining its basic underlying assumptions.

\section{Location and the spatial structure of the FUA of Kotobrzeg}

Kołobrzeg's FUA (Functional Urban Area) consists of the municipality of Kołobrzeg, the surrounding rural communities, and Ustronie Morskie. It occupies an area of $226.68 \mathrm{~km}^{2}$ and in 2012 it was inhabited by a total of 60,750 inhabitants with an average population density of 268 persons/ $\mathrm{km}^{2}$. According to the Central Statistical Office, in 2013, on this area, there were over 32,000 beds and, according to the author's own research work, there were nearly 100,000 beds. The FUA covers the northern part of the district of Kołobrzeg and is a linear spatial arrangement which extends along the coastline of the Baltic Sea, with a length of over 25 kilometers. The development of the settlement and its tourism have led to an almost continuous linear settlement system with a length of over $25 \mathrm{~km}$ of the target based on dual carriageways S-6 and S-11 and the Light Rail Seaside (LKN) along the coastline ${ }^{2}$ (Figure 1).

The FUA includes several important tourist destinations: Kołobrzeg (pop. 47,000; approx. 48,000 beds), Ustronie Morskie (pop. 2,200; approx. 16,300 beds), Grzybowo (pop. 1,650; approx. 9,900 beds), Dźwirzyno (pop. 710; approx. 17,500 beds), Sianożęty (pop. 450; approx. 6,300 beds), Wieniotowo (pop. 250; approx. 800 beds). Other FUA places with a very small number of beds are Zieleniewo (pop. 2,450), Budzistowo (pop. 824), Niekanin (pop. 405), Korzystno (pop. 390), Stramnica (pop. 271), and Kądzielno (pop. 267). The seaside population in 2013 reached approximately 52,260, while the entire population of the FUA was over 56,867. The total number of beds reached almost 100,000.

${ }^{1}$ Transport Policy, City of Kołobrzeg, 2015.

${ }^{2}$ M. Miedziński, Miasto Kołobrzeg wiodącym uzdrowiskiem Polski i jednym z centrów turystycznych kraju, in: Ekonomiczne i organizacyjne aspekty funkcjonowania polskich uzdrowisk, ed. E. Rydz, Wydawnictwo Akademii Pomorskiej, Słupsk 2012, pp. 139-150. 


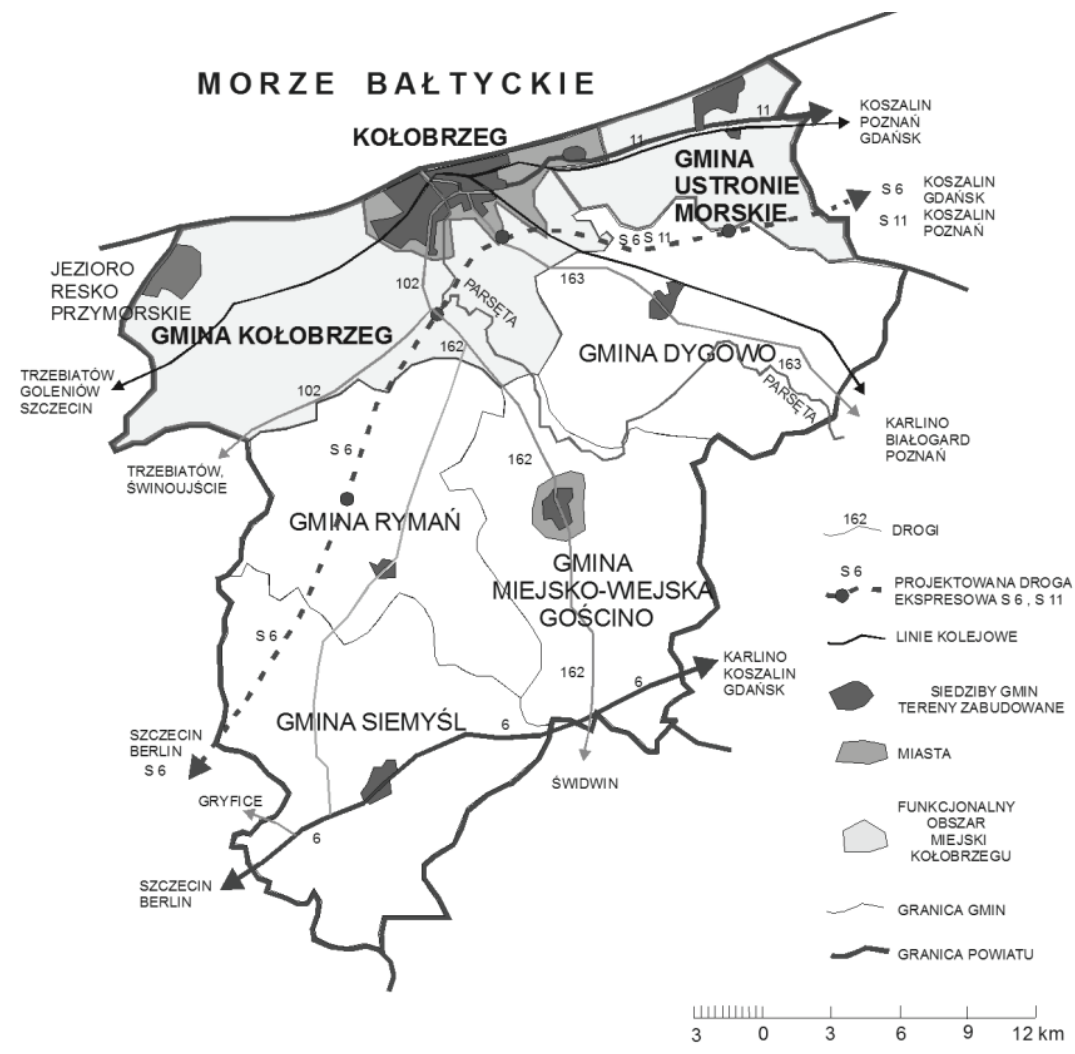

Figure 1. Location and the spatial structure of the tourist region FUA Kołobrzeg

Source: my own research and development.

\section{TALC in the light of the Threshold Theory}

A breakthrough study in tourism is the TALC theory. This theory was published by R.W. Butler in 1980 in the journal "The Canadian Geographer." phases similar to the product life cycle in economic research:

- the exploration phase (discovery),

- implementation phase (introduction),

- growth phase of consolidation (maturity),

- stagnation phase (saturation), and the

- rebirth/fall phase (fall/rebirth).

${ }^{3}$ R.W. Butler, The Concept of a Tourist Area Cycle of Evolution: Implications for Management of Resources, “The Canadian Geographer" 1980, Vol. 24, pp. 5-12. 
The modifications made by other authors have allowed for the addition of a stabilization phase (change ${ }^{4}$ or restore its functions) and regeneration, as well as, reorientation and stagnation phases. ${ }^{5}$ The concept of TALC by R.W. Buttler has been analyzed and modified repeatedly. Substantial modification of the life cycle of the tourist area in the area of terminology has been introduced by R. Szromek who substitutes the term of the phase of stagnation for the phase of the blooming period. ${ }^{6}$ The analysis of the classic life cycle of a tourist area in the consolidation and prosperity phase also includes a zone of maximum absorbency and tourist capacity, which ultimately may result in a falling or rebirth, also called the post-blooming period. ${ }^{7}$ The authors of numerous studies indicate the possibility of recovery (revival) implemented by deliberate and comprehensive actions to improve the attractiveness of the tourist area, allowing for the start of a new TALC ${ }^{8}$, which would confirm the P. Defert's thesis. ${ }^{9}$ The revitalization and restoration of beaches and the attractions offered by the Kołobrzeg resort area carried out in recent years and the significant improvement in the quality of accommodation and accompanying services confirms the maintainence of the existing TALC or the possibility of creating the new TALC cycle. According to the supplemental material in 2000 by R.W. Butler, the TALC concept and its extension in 2006, the TALC course is a dynamic, long-term phenomenon that could have universal application. Generally, the analysis of the TALC course is possible to interpret only after many years, and forecasting the future course of development of this tourist area is difficult. Over the past several years, numerous studies have tested this concept,${ }^{10}$ confirmed its authenticity, ${ }^{11}$ pinpointed its imperfections, ${ }^{12}$ or supplemented TALC with new elements. ${ }^{13}$

${ }^{4}$ C.S. Johnston, Shoring the Foundations of the Destination Life Cycle Model, Part 1, "Ontological and Epistemological Considerations Tourism Geographies” 2000, No. 3 (1), pp. 2-28

${ }^{5}$ S. Agarwal, Coastal Resort Restructuring and the TALC Model, in: The Tourist Area Life Cycle. Conceptual and Theoretical Issues, ed. R.W. Butler, Channel View Publications, Clevedon 2006, pp. 201-218.

${ }^{6}$ A.R. Szromek, Cykliczność rozwoju uzdrowisk na przykładzie uzdrowisk polskich, in: Uzdrowiska i ich znaczenie w gospodarce turystycznej, ed. A.R. Szromek, Proksenia, Kraków 2010, pp. 17-40, 280.

${ }^{7}$ S. Agarwal, Restructuring Seaside Tourism. The Resort Lifecycle, “Annals of Tourism Research” 2002, No. 29 (1), pp. 25-55.

${ }^{8}$ M. Oppermann, What is New With the Resort Cycle? Comment, "Tourism Management" 1998, Vol. 19, pp. $181-183$.

9 P. Defert, Essaie de localization touristique, "Tourist Review" 1954, Vol. 9 (1), p. 119.

${ }^{10}$ Lundtrop S., S. Wanhill, The Resort Lifecycle Theory. Generating Processes and Estimation, „Annals of Tourism Research" 2001, No. 28 (4), pp. 947-964; Z. Kruczek, A.R. Szromek, Wykorzystanie modelu R. W. Butlera w interpretacji rozwoju atrakcji turystycznej na przykładzie kopalni soli w Wieliczce, „Folia Turistica” 2011, No. 25 (2), pp. $275-289$.

${ }^{11}$ R.M. Lagiewski., The Application of the TALC Model: A Literature Survey, in: The Tourism Area Life Cycle, ed. R.W. Butler), Channel View Publications, Clevedon-Buffalo-Toronto 2006, p. 27.

12 K.M. Haywood, Can the Tourist Area Life-Cycle Be Made Operational?, "Tourism Management” 1986, No. 7 (3), pp. 154-167; K.M. Haywood, Evolution of Tourism Areas and the Tourism Industry, in: The tourism area life cycle, ed. R.W. Butler, Vol. 1, "Applications and modifications”, Channel View Publications, Clevedon-Buffalo-Toronto 2006, pp. 51-70.

${ }^{13}$ S. Corak, The Modification of the Tourism Area Life Cycle Model for Re(Inventing) a Destination: the Case of the Opatija Riviera, Croatia, in: The Tourism Area Life Cycle, ed. R.W. Butler, Vol. 1, "Applications and modifications", Channel View Publications, Clevedon-Buffalo-Toronto 2006, pp. 271-288; S. Lundtorp, S. Wanhill, Time Path Analysis and TALC Stage Demarcation, in: The Tourism Area Life Cycle, ed. R.W. Butler, Vol. 2, "Conceptual and theoretical issues", Chanel View Publications, Clevedon-Buffalo-Toronto 2006, pp. 138-149. 
An analysis of the modified TALC of a typical tourist town (Figure 2) equally compares to the TALC of Kołobrzeg and demonstrates the significant similarities in their courses ${ }^{14}$ (Figure 3).

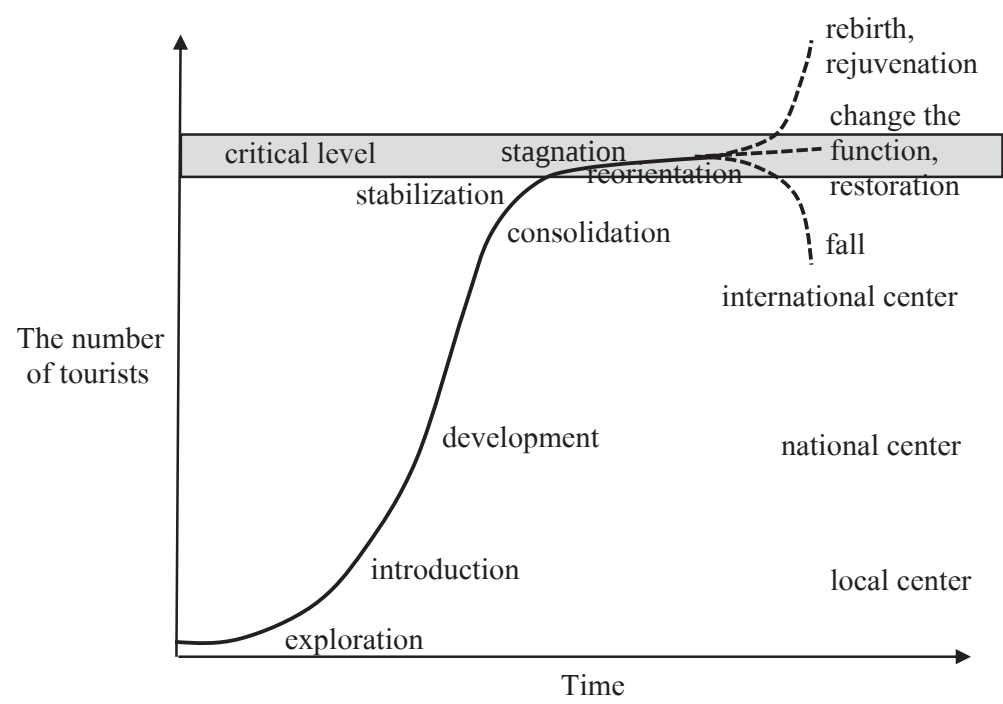

Figure 2. Classical modified tourist area life cycle. R. W. Butler and subsequent changes made by other authors Source: R.W. Butler, Tourist Area Life Cycle, in: (CTR) Contemporary Tourist Reviews, OX3 9TJ, Oxford 2011, p. 33.

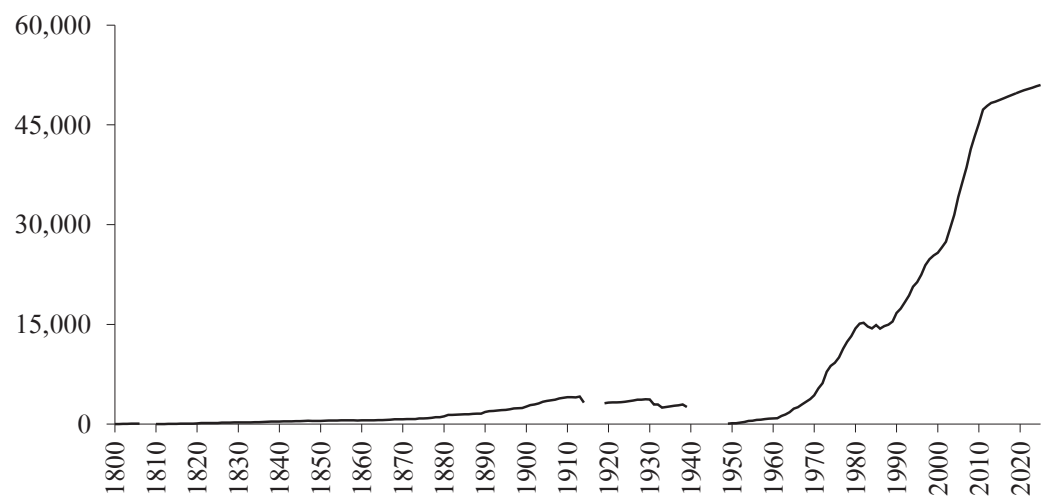

Figule 3. Changes in the number of beds in Kołobrzeg the years 1800-2025

Source: my own research and development.

\footnotetext{
${ }^{14}$ M. Miedziński, Rozwój przestrzenny uzdrowiska Kolobrzeg od 1830 do 2009 roku oraz przemiany jego bazy noclegowej w latach 1989-2009, in: W trosce o przyszłość kołobrzeskiego uzdrowiska - międzynarodowe forum uzdrowiskowe, ed. E. Wiśniewski, Regionalne Stowarzyszenie Turystyczno-Uzdrowiskowe, Kołobrzeg, Wydawnictwo INTRO-DRUK, Koszalin 2009, pp. 124-137.
} 
In the course of the Kołobrzeg cycle, there have been significant gaps between the phases of intensive growth (boom) and retardation or even regression (slump). These periods are irregular fluctuations, however, and can be studied, as well as the occurrence of developmental thresholds, in important historical references.

Threshold development problems in tourist areas refer to the Threshold Theory by B. Malisz and allow the same as in the case of urban development with designated levels of development in the tourist area and in the broader understanding of the tourist space. In many cases, especially in small or young tourist areas, we are dealing with a long life cycle of the area (tourist town). In a significant number of cases where the life cycle is quite long, expansion of the tourist area happens in stages, and these stages are characterized by the development of accelerations ( $D$ pulses) during, for example, an economic boom, stagnation of development, or a severe economic downturn.

Studying the long course of the TALC of Kołobrzeg enables you to highlight not only two, or even three, cycles of life but also allows the use of the Threshold Theory for modification and analysis of the course of TALC.

In the case of Kołobrzeg, the Threshold Theory indicates that this tourist area has probably already begun the process of further extending the life cycle of the next stage of growth even though the city over a period of several years from 2007-2012 had a slowdown in the development of hotel accommodation. Kołobrzeg which was in the developmental phase, slowed down the pace of development of the accommodation facilities with a significant, constant increase in overnight stays making efficient use of services.

\section{Outline of the Threshold Theory by B. Malisz}

In line with B. Malisz's Threshold Theory, ${ }^{15}$ city and urban areas face important limitations in their development in population and spatial development. Among these limitations are:

- physical constraints (resulting from the diversity of physio-graphic features of the site),

- functional limitations (due to the form of land use),

- technological limitations (due to the characteristics of the technical infrastructure),

- $\quad$ structural constraints (due to the need to restructure the land).

Each limit may be exceeded in order to further the development of the city; however, this process is associated with the crossing of significant financial outlays as well as with an increase in operating costs of the city/urban areas (for example, the cost of infrastructure development in Kołobrzeg including the expansion of the beaches, reconstruction of the transportation system, and the modernization service infrastructure of the city.)

The capital and fixed costs in the course of the operation and development of the city are those thresholds, and the cost of exceeding a given threshold is not continuous but is achieved in stages (increments) and the jumps are in turn determined by the threshold key constraints.

${ }^{15}$ B. Malisz, Metoda analizy progowej w zastosowaniu do planowania miast i regionów, in: Metoda analizy progowej, eds. B. Malisz, J. Żurkowski, Studia KPZK PAN, No. 34, Warszawa 1971, pp. $27-47$. 
Clearly the visible threshold of development for the city of Kołobrzeg and for Kołobrzeg FUA is the reconstruction and expansion of the transport system (Figures 4, 5).
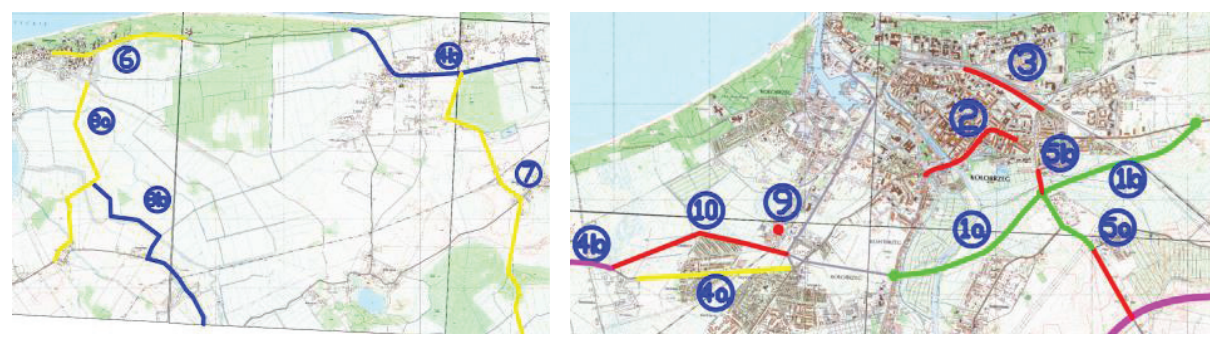

Figure 4. Investments Road FUA Kołobrzeg 2015-2020

Source: Transport policy NOF Kołobrzeg.

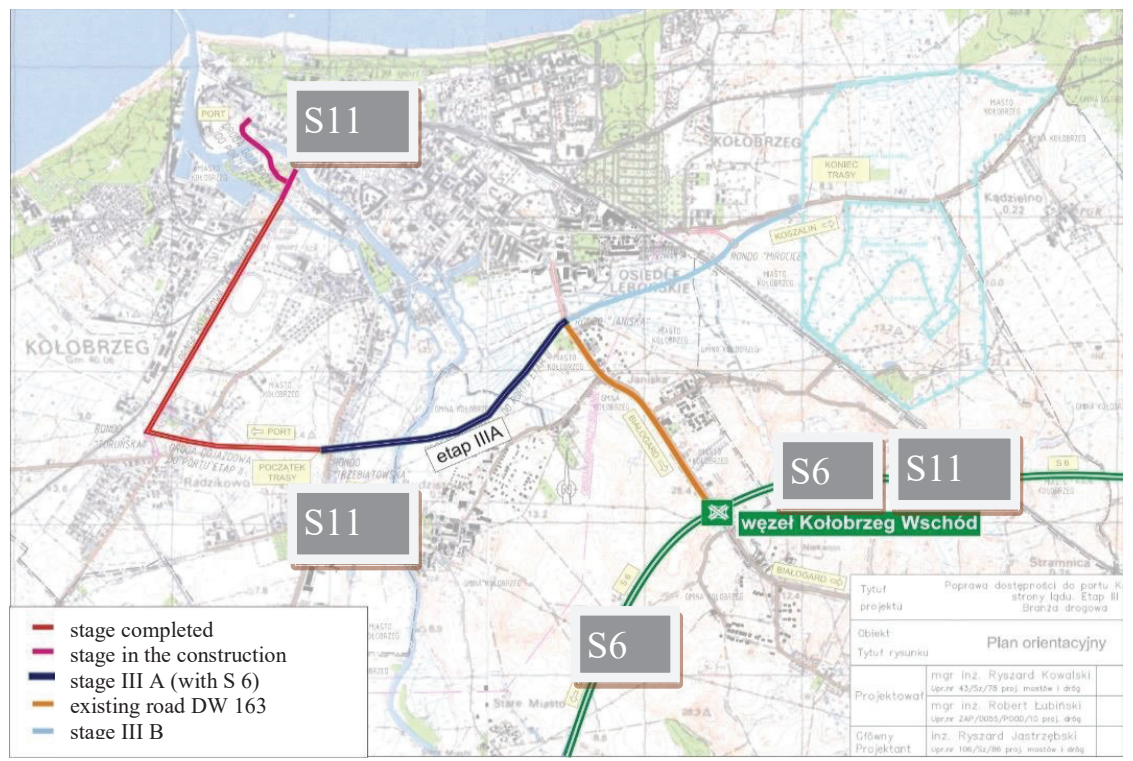

Figure 5. Target mileage of expressways S-6 and S-11 in Kołobrzeg

Source: Transport policy NOF Kołobrzeg.

Its investments (Figures 4, 5) confirm the phenomenon of crossing the threshold of the FUA Kołobrzeg development and especially the city of Kołobrzeg. The construction of a new communication system and modernization of the existing road network that will be built here make spatial arrangement supported by two ring roads. The Outer Ring Road around Kołobrzeg streamlines the movement throughout the FUA as expressway S-6 and S-11 part, and the inner ring 
road serves as the final section of the S-11 around the downtown area leading from the east to the Kołobrzeg seaport junction in Kołobrzeg (Figures 4, 5).

Another measure that allows one to determine the current stage of the Threshold Theory in Kołobrzeg may be the number of dwellings (or chambers) on a global basis and the scale of the increase in housing stock, expressed in their overall floor area in $\mathrm{m}^{2}$ (Table 1). ${ }^{16}$

Table 1. Housing and population Kołobrzeg in the years 1988-2013

\begin{tabular}{ccccc}
\hline Year & $\begin{array}{c}\text { Number } \\
\text { house }\end{array}$ & $\begin{array}{c}\text { Number } \\
\text { rooms }\end{array}$ & $\begin{array}{c}\text { Usable area } \\
\text { house in } \text { m }^{2}\end{array}$ & $\begin{array}{c}\text { The number } \\
\text { of residents }\end{array}$ \\
\hline 1988 & 12,551 & nd. & 670,063 & 43,538 \\
1995 & 14,469 & 49,764 & 800,917 & 47,301 \\
1996 & 14,623 & 50,463 & 815,177 & 47,480 \\
1997 & 14,685 & 50,803 & 823,021 & 47,886 \\
1998 & 14,787 & 51,250 & 833,933 & 48,082 \\
1999 & 14,927 & 51,877 & 847,585 & 45,029 \\
2000 & 15,065 & 52,484 & 863,414 & 45,107 \\
2001 & 15,356 & 53,423 & 887,266 & 44,995 \\
2002 & 17,153 & 61,862 & $1,084,167$ & 44,803 \\
2003 & 17,417 & 62,803 & $1,102,515$ & 44,834 \\
2004 & 17,682 & 63,541 & $1,119,308$ & 44,932 \\
2005 & 18,044 & 64,492 & $1,147,333$ & 44,887 \\
2006 & 19,034 & 66,616 & $1,205,703$ & 44,737 \\
2007 & 19,387 & 67,552 & $1,235,475$ & 44,889 \\
2008 & 19,841 & 68,588 & $1,273,972$ & 44,925 \\
2009 & 20,495 & 70,315 & $1,313,295$ & 44,991 \\
2010 & 21,275 & 82,206 & $1,445,702$ & 47,103 \\
2011 & 21,442 & 82,659 & $1,457,244$ & 47,078 \\
2012 & 21,835 & 83,662 & $1,480,514$ & 46,951 \\
2013 & 22,021 & 84,299 & $1,492,066$ & 46,897 \\
\hline
\end{tabular}

nd. - no data.

Source: Central Statistical Office data for the years 1988-2013. A Compilation.

In comparing the population growth $(7.7 \%)$, the increase in the total number of dwellings $(175.5 \%)$, and in particular, their usable area $(222.5 \%)$, over the past 25 years, it can be concluded that Kołobrzeg has exceeded the threshold of sized residential development without increasing the constant population significantly while increasing the accommodation capacity of the city in the form of thousands of "second houses" and "second apartments" (Figure 6).

The spatial development of the city or the increase of the housing can be done at no cost to the threshold; however, it will take place at the expense of quality living conditions augmenting functional problems through an increase in load factors and density of the existing structure of the settlement. The preservation, and in particular, improvement of the conditions for the functioning of the urban area requires crossing the threshold of development as a result of spatial and demographic advancement.

${ }^{16}$ J. Kozłowski, Analiza progowa, Prace Instytutu Kształtowania Środowiska, PWN, Warszawa 1974, p. 101. 

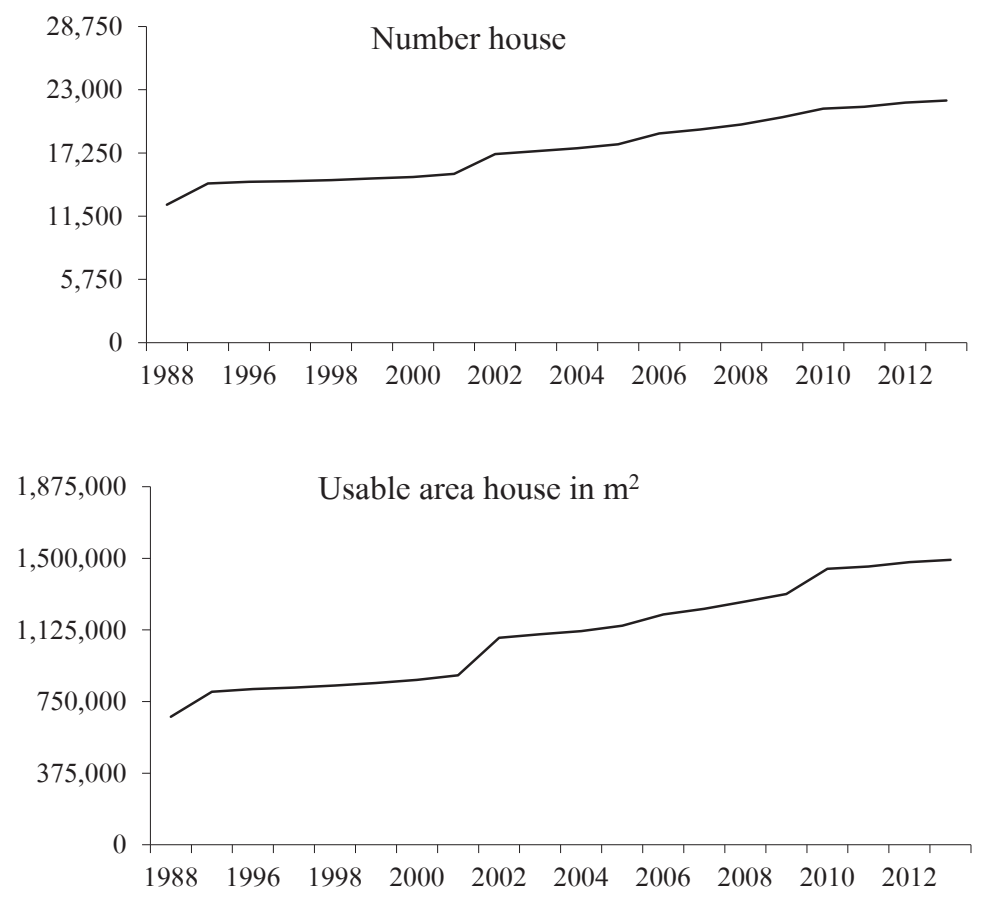

Figule 6. Increase in housing stock in Kołobrzeg

Source: my own research and development.

To sustain such an intense development of Kołobrzeg's tourist accommodation facilities it was essential to cross the first post-war threshold of development in the form of investment in municipal infrastructure and technical support of the city. This took place in the late 1970s and the 1980s. The final crossing of the threshold of the pre-war development was carried out by architectural reconstruction, reconstruction and expansion of water supply system, sewage, gas, energy, telecommunications, and city heat sources. Heating sources were renovated in the city, lowcarbon sources of air pollution were eliminated, the old waste water treatment plant was improved and expanded and a new ground water treatment plant was built, a garbage composting center was constructed, and the municipal transport fleet was modernized. The process culminated in the modernization and completion of the old pre-war spatial structure and infrastructure of the city.

Kołobrzeg's surmounting of the threshold of the second post-war development was associated with the renovation of very large areas of former military grounds in Kołobrzeg and the construction of new residential, commercial, and health retreats. Stage I beat the previous threshold of development (technical and municipal infrastructure of the city), therefore allowing a later phase of development of the city to start crossing stage II of Kołobrzeg's development threshold for residential and health resort areas (new residential housing and accommodation in the form of an increased number of tourist and spa facilities and "second houses" and "second apartments") while at the same time beginning reconstruction of the transportation system of the city and the FUA. 
As part of the current second threshold, developments already completed or performed services are objects of regional rank (completed Regional Sports Centre and the Regional Cultural Centre, modernized Regional Hospital, current construction of a third docking area of Yacht Marina Kołobrzeg, construction of two large shopping malls; since September 2012, the airport operates for seasonal sports and tourism with profits being invested in the development of the commercial port, fishing and passenger transport including ferry connections). Also important is the planned construction of the Regional Center of Innovation Administration and the LKN.

The next step in crossing the threshold stage II is developing major road projects (highways S-6 and S-11) also taking into account the expected change in the administrative boundaries of the city of Kołobrzeg and assuming the simultaneous absorption of several towns around Kołobrzeg, thus exceeding Kołobrzeg's current city population of 50,000 permanent residents. It is important also to create a FUA called Seaside Functional Area of Kołobrzeg up to a dozen kilometers from Kołobrzeg within the northern part of the region where the major factors are the tourist and spa suburban zones. The expected end result of the threshold stage II development for Kołobrzeg is a fully functional FUA governed by three municipalities (city of Kołobrzeg, commune of Kołobrzeg, and commune of Ustronie Morskie). It is also possible that the elimination of both rural communities combined with the simultaneous establishment of the city's new administrative commune status boundaries could receive multimillion zloty government support due to mergers and liquidation of smaller local governments.

The tight integration of both the city and commune municipalities can lead to obtaining higher status in this area of the district which covers the coastal strip of the Baltic Sea. This important area has a total length of $30 \mathrm{~km}$ running along the Baltic Sea coastline and a width of several kilometers which stretches from the Baltic Sea along the expressway S-6 Szczecin-Gdańsk that runs along the southern border of the FUA. If obtained, the multimillion zloty government aid could be used in carrying out the process of full integration of spatial, functional, and social communication of all the FUA towns in extended administrative boundaries. The area is now home to almost 57,000 people and, by 2030, it is expected that there could be as many as 70,000 permanent residents.

Tourism and spa accommodations of the FUA have already attained a volume of 100,000 beds in 2013, and ultimately could reach more than 130,000 beds. It is approximated that by the year 2030, FUA outside the summer season will be able to count more than 100,000 inhabitants, tourists, and patients; while in the summer the number of people may exceed 200,000. Today, on a typical tourist weekend, approximately $25,000-30,000$ people may be staying in the FUA; by the year 2030, this figure could reach approximately 50,000 people provided communication with the agglomeration of Poznań (modernized railway line and the road S-11) is improved. It should also be noted that by 2030 , the total target population, including tourists, that could be living a day in the season of happiness on the coast of Kołobrzeg could reach 250,000 people. This number represents the target capacity of the FUA's $30 \mathrm{~km}$ of beaches assuming a beach area of $10 \mathrm{~m}^{2} /$ person. 


\section{Modification of the TALC on the basis of the Threshold Theory}

Using the above information on the range of the recent increase of population in the city of Kołobrzeg, accommodation capacity of "second homes" and "second apartments" and all formal and informal accommodation facilities used for tourism purposes can be improved by an adjusted model of threshold development. Hence the need for the appointment of key thresholds relevant to the development of such a model.

Using the threshold theory by Malisz that has been modified by Kozłowski and the TALC developed by Butler based on the life cycle of the tourist village, the building and running of a new "threshold tourist area life cycle - TTALC" can be proposed (Figure 7).

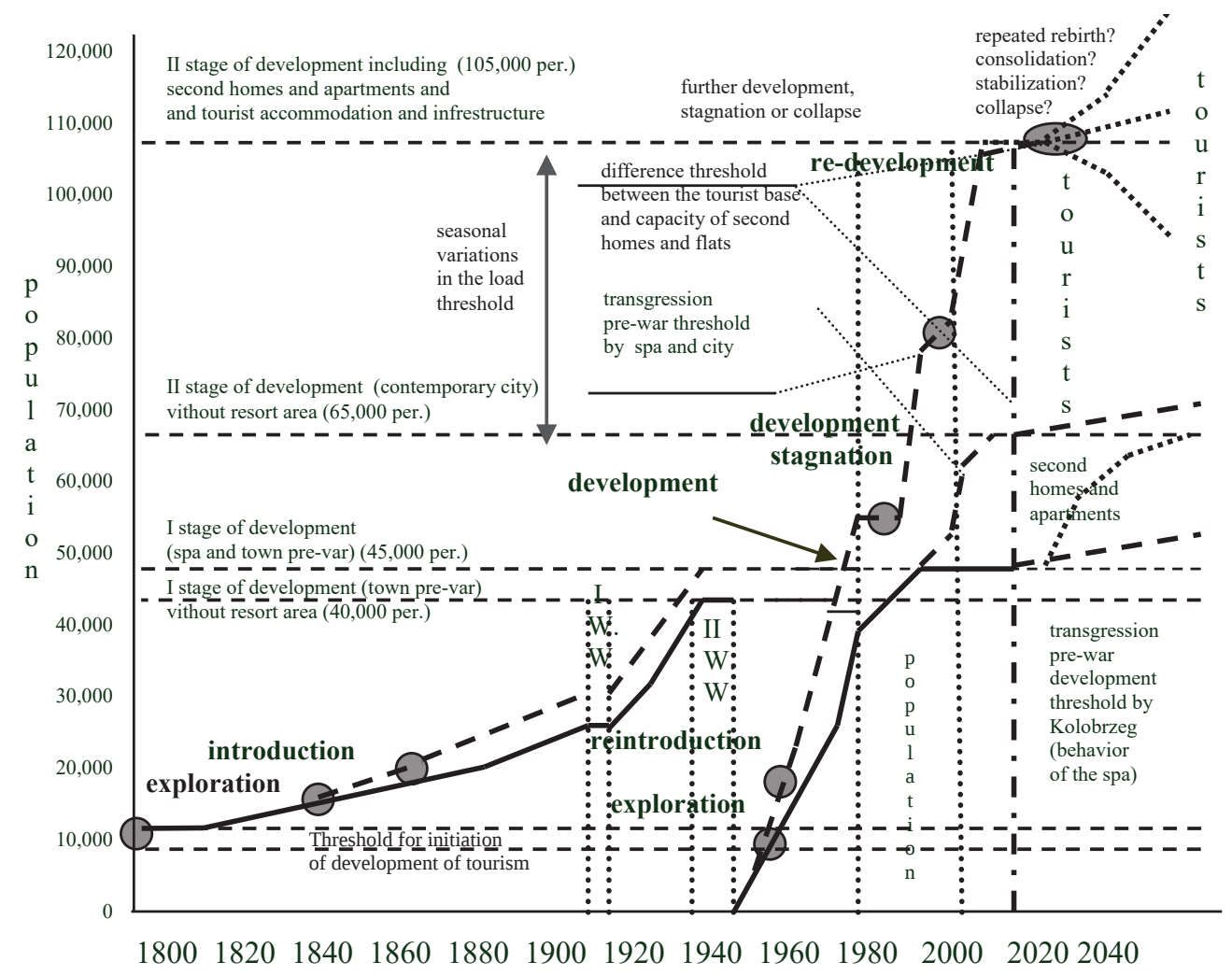

Figure 7. Change of the potential tourist area life cycle in Kolobrzeg (the concept published for the first time in 2013) $)^{17}$

Source: my own research and development.

${ }^{17}$ M. Miedzinski, Modyfikacja cyku życia obszaru turystycznego (TALC) w wyniku wprowadzenia założeń teorii progowej na bazie przestrzeni turystycznej Kołobrzegu i jego zaplecza, in: Współczesne problemy rozwoju turystyki w ujęciu regionalnym i lokalnym, eds. R. Jaroszewska-Brudnicka, D. Sokołowski, UMK Toruń, Toruń 2013, pp. $213-228$. 
The range of the current course of spatial processes and functional changes that took place in Kołobrzeg is incomparable to any other Polish tourist area allowing one to attempt a modification of Butler's classic TALC by introducing a series of threshold elements which are closely linked to Malisz's Threshold Theory (Figure 8), thus forming the concrete premises of the threshold tourist area life cycle (TTALC). Determined on the basis of many years of research on the life cycle in the tourist area of the city - the health resort zone of Kołobrzeg, three very clearly defined periods stages - phases can be seen.

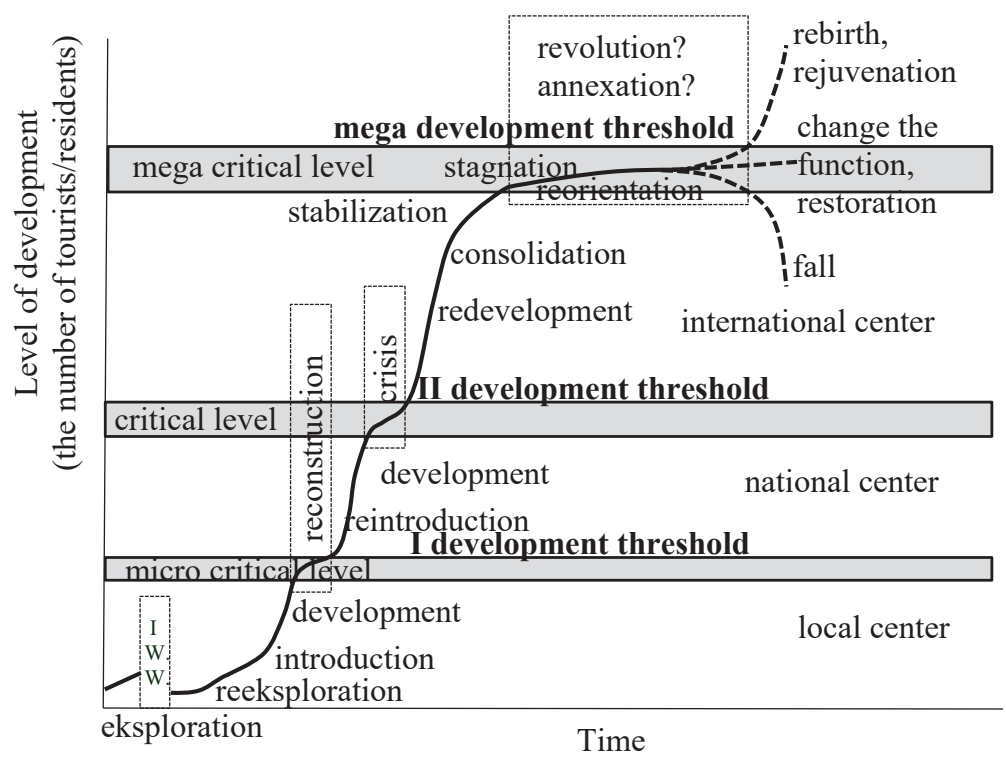

Figure 8. Proposal of the modified threshold tourist area life cycle developed on the basis of R.W. Butler, taking into account changes made by other authors

Source: own calculations based on R.W. Butler, Tourist Area Life Cycle, in: (CTR) Contemporary Tourist Reviews, OX3 9TJ, Oxford 2011, p. 33.

The derived model TTALC (Threshold Tourist Area Life Cycle) for Kołobrzeg (Figure 8) indicates the possibility of introducing a modified TTALC, the course of which would be adjusted according to the determinants of the threshold theory (i.e. population, housing, second homes and apartments, changes in the communication system, historical events) by B. Malisz and Kozłowski (Figure 8).

This model can also be applied to small tourist areas which were similarly tested and presented (Figures 9-14). 


\section{TTALC Models for selected locations FUA Kołobrzeg}

The development of the FUA of Kołobrzeg was parallel to the development of the city of Kołobrzeg. The city has the longest TALC reaching back to 1830, while in the neighboring towns tourist functions developed decades later, at the same time showing significant spatial variation. Each of the analyzed villages and towns are characterized by a great diversity in time, scale, and TTALC progression (Figures 9-14).

An analysis of the development processes taking place in the tourist area of the FUA allows for a clear differentiation of those processes in the context of a modified TALC. Detailed studies of the stages of the life cycle have been carried out in six FUA villages and towns which constitute the most equipped and urbanized part of the district of Kołobrzeg. These places represent different life cycles and modification of their course is strongly determined by historical events, political decisions, changes in population size, and changes in the pace and scope of the expansion of tourist accommodations including second houses and apartments. Each of these locations also have significant functions that help form the nature of the dominant and most popular facilities. It is also possible to set developmental thresholds based on previously planned or existing tourist destinations. Interestingly, there is even a strong variation between the villages in a single settlement system - in this case, FUA Kołobrzeg.

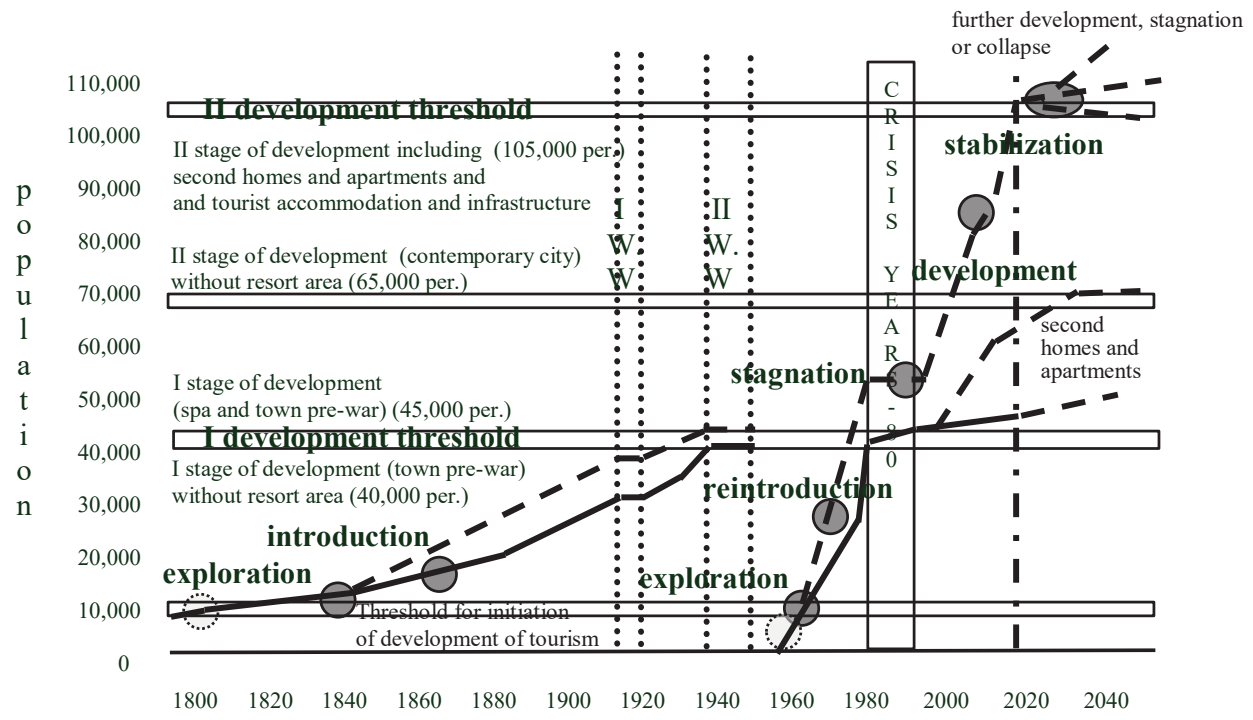

Figure 9. TTALC models for selected villages of the FUA of Kołobrzeg - Kołobrzeg (pop. 47,000; approx. 48,000 beds)

Source: the author's compilation. 


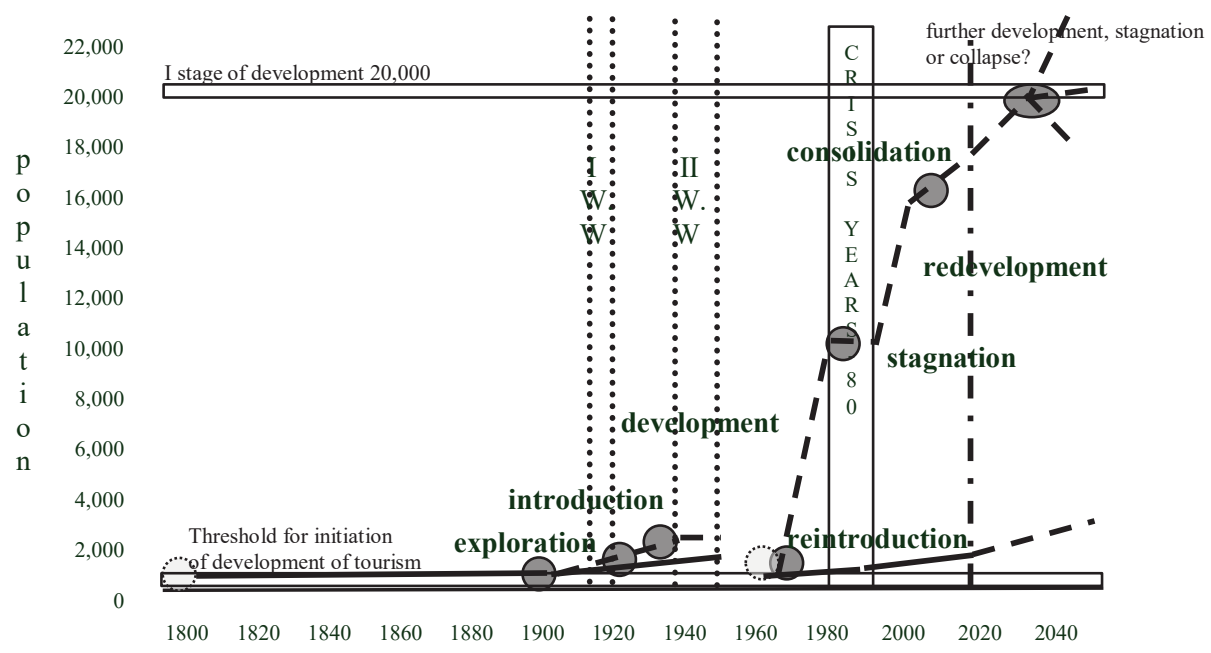

Figure 10. TTALC models for selected villages of the FUA of Kołobrzeg - Dźwirzyno (pop. 710; approx. 17,500 beds)

Source: the author's compilation.

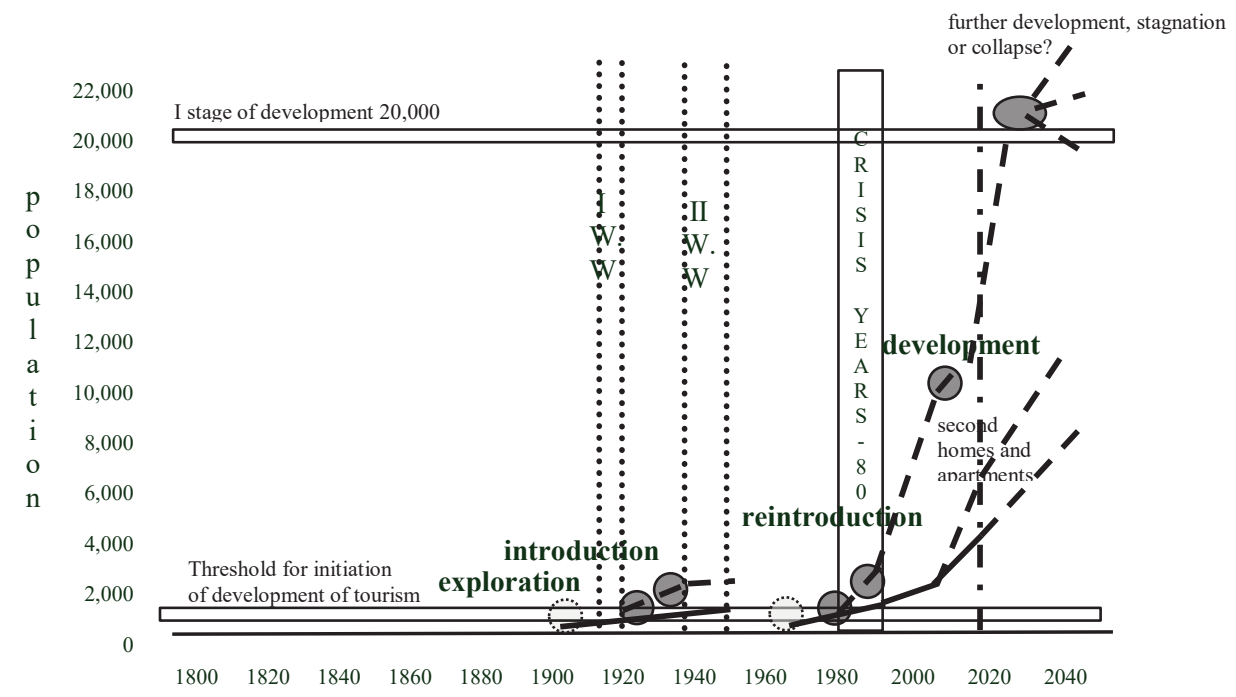

Figure 11. TTALC models for selected villages of the FUA of Kołobrzeg - Grzybowo (pop. 1,650; approx. 9,900 beds)

Source: the author's compilation. 


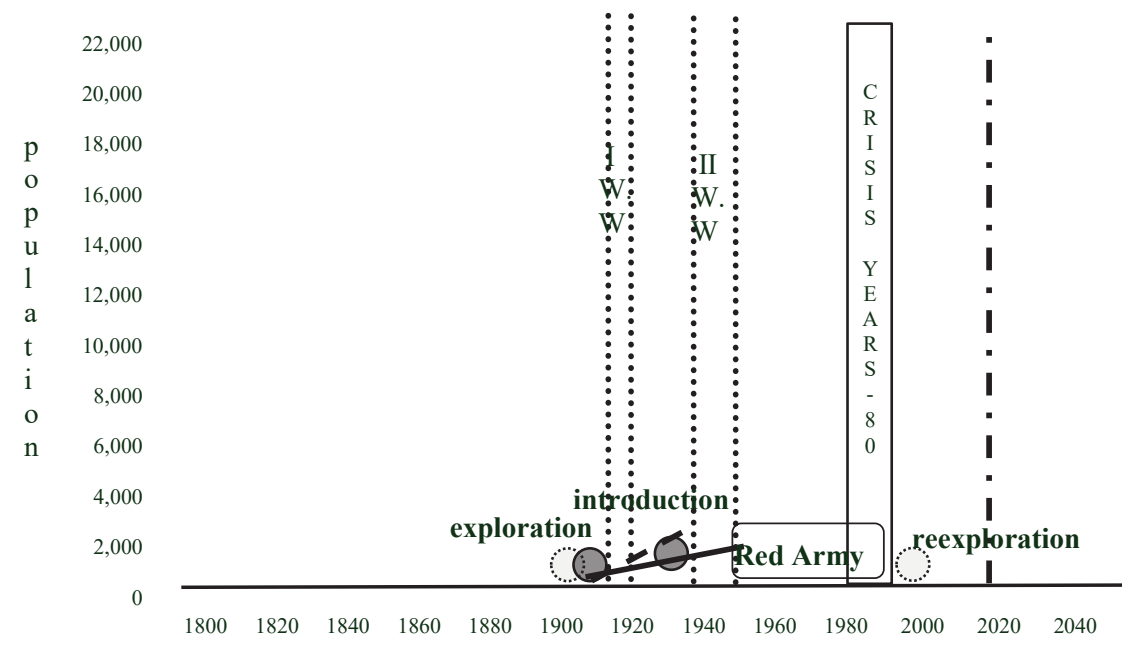

Figure 12. TTALC models for selected villages of the FUA of Kołobrzeg - Bagicz (pop. 10; 0 beds)

Source: the author's compilation.

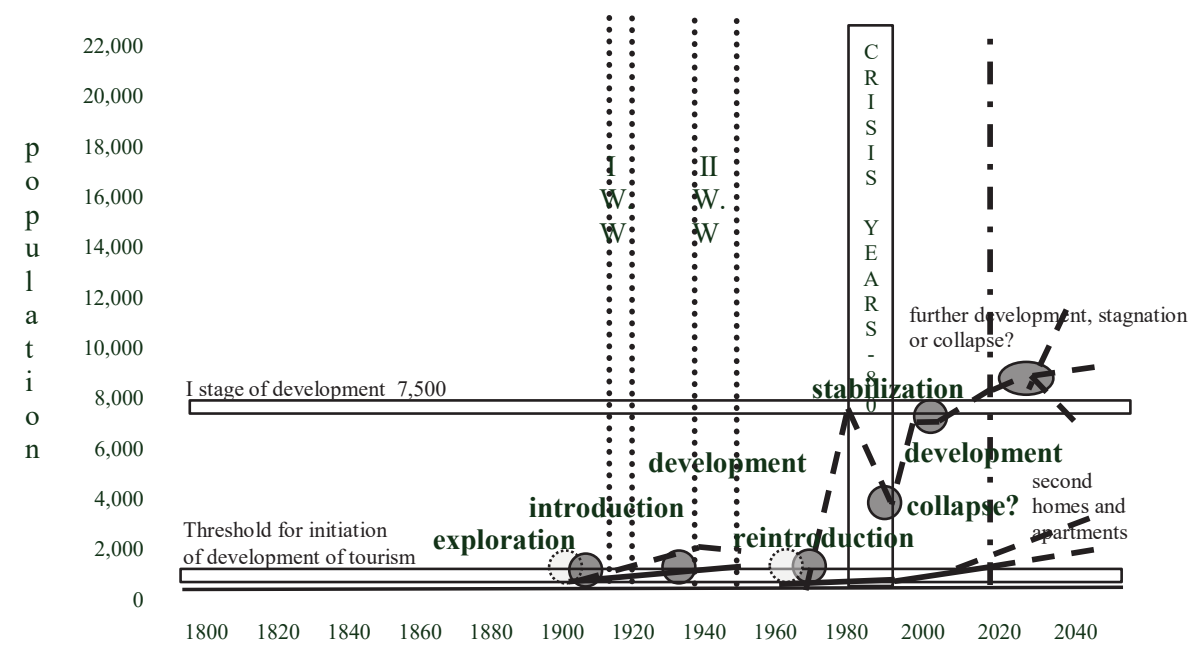

Figure 13. TTALC models for selected villages of the FUA of Kołobrzeg - Sianożęty (pop. 450; approx. 6,300 beds)

Source: the author's compilation. 


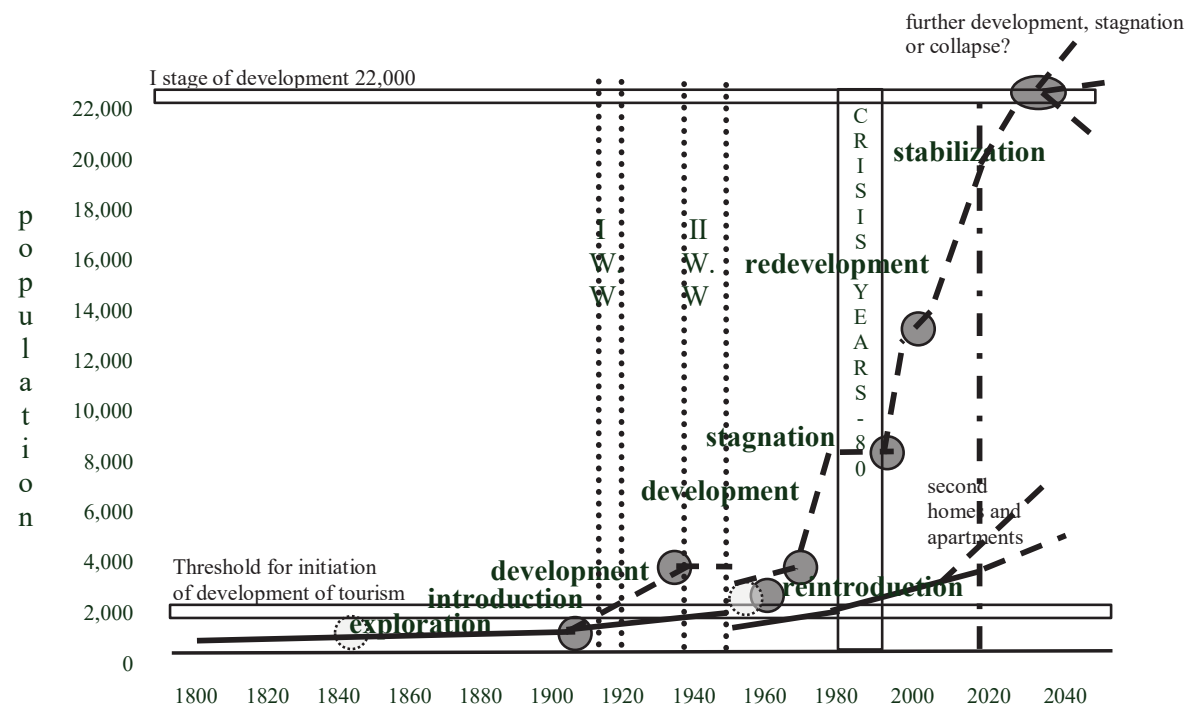

Figure 14. TTALC models for selected villages of the FUA of Kołobrzeg - Ustronie Morskie (pop. 2,200; approx. 16,300 beds)

Source: the author's compilation.

\section{Conclusion}

Kołobrzeg, in the first decade of the 21st century, reached a milestone in its urban spatial and functional development in the context of both the traditional TALC and the classical theory of thresholds. In the proposed model of the "threshold tourist area life cycle" (TTALC), the author, using Kołobrzeg as an example, combines the classic TALC with the threshold theory.

Using the TTALC model it can be concluded that:

1. When taking into account the current TTALC developmental thresholds, each arbitrarily chosen tourist area can develop according to the classical modified TALC.

2. The key developmental thresholds are physical, functional, technological and structural limitations. Developmental determinants should also include such phenomena as armed conflict, economic crises, revolutions, political and territorial changes. In reference to the TTALC model, these determinants can be mentioned.

3. The existing classic TALC usually included one unbroken life cycle not encompassing the usual associated accelerations and decelerations (fluctuations) involved in its long run.

4. The simplification of a graph of the long course of TALC and its multi-step developmental cycles may be supplemented by the threshold determinants allowing for more accuracy in the course of the TTALC.

5. In the course of the TTALC analysis two factors should be taken into consideration: changes in the demographic potential and capacity of second homes and apartments in the tourist 
area and the location of temporary key infrastructure investments through which have been or will be achieved developmental limits in the study area.

6. In the analysis of the tourism capacity and related developmental thresholds for each tourist resort or area, three components should be taken into account on the basis of the size of the active publicly accessible tourist accommodation data: the fixed population (residents), the number of residential population (owners of second homes and apartments), and the number of semi-permanent tourists (patients). These figures allow us to set a threshold for the development of a village or town as well as other specific thresholds; for example: a year-round tourist threshold, a seasonal tourist threshold, a typical residental threshold, a residental development threshold (second homes and apartments), and the development thresholds including the peak (seasonal) thresholds for a given locality or tourist area.

7. The TTALC allows for precise determination of the level of development of the tourist area in the past, present, and foreseeable future, taking into account the population and the capacity of second homes and apartments and tourist accommodation.

8. The analysis carried out, combined with the ability to apply in practice in the example of Kołobrzeg and its FUA, allow us to believe that the proposed TTALC will be helpful in conducting the researches made in various towns and tourist areas.

R.W. Butler's classic theory of TALC and B. Malisz's Threshold Theory show some similarity and compatibility with respect to each other resulting in the proposed TTALC. These features allowed us to derive a new joint model under the name Threshold Tourist Area Life Cycle. The proposed model obviously requires further research and empirical confirmation.

\section{Referennces}

Agarwal S. Coastal Resort Restructuring and the TALC Model, in: The Tourist Area Life Cycle. Conceptual and Theoretical Issues, ed. R.W. Butler, Channel View Publications, Clevedon 2006.

Agarwal S. Restructuring Seaside Tourism. The Resort Lifecycle. "Annals of Tourism Research” 2002, No. 29 (1).

Butler R.W., The Concept of a Tourist Area Cycle of Evolution: Implications for Managment of Resources, "The Canadian Geographer" 1980, Vol. 24.

Butler R.W., Tourist Area Life Cycle, in: (CTR) Contemporary Tourist Reviews, OX3 9TJ, Oxford 2011.

Corak S. The Modification of the Tourism Area Life Cycle Model for Re(Inventing) a destination: the Case of the Opatija Riviera, Croatia, in: The Tourism Area Life Cycle, ed. R.W. Butler, Vol. 1, "Applications and modifications", Channel View Publications, Clevedon-Buffalo-Toronto 2006.

Defert P., Essaie de localization touristique, "Tourist Review” 1954, Vol. 9 (1).

Haywood K.M., Can the Tourist Area Life-Cycle be Made Operational?, “Tourism Management” 1986, No. 7 (3).

Haywood K.M., Evolution of Tourism Areas and the Tourism Industry, in: The Tourism Area Life Cycle, ed. R.W. Butler, Vol. 1, "Applications and modifications", Channel View Publications, Clevedon-Buffalo-Toronto 2006.

Johnston C.S., Shoring the Foundations of the Destination Life Cycle Model, Part 1, "Ontological and Epistemological Considerations Tourism Geographies" 2001, No. 3 (1).

Kozłowski J, Analiza progowa, Prace Instytutu Kształtowania Środowiska, PWN, Warszawa 1974.

Kruczek Z., Szromek A.R., Wykorzystanie modelu R.W. Butlera w interpretacji rozwoju atrakcji turystycznej na przyktadzie kopalni soli w Wieliczce, „Folia Turistica” 2011, No. 25 (2).

Lagiewski R.M., The Application of the TALC Model: A Literature Survey, in: The Tourism Area Life Cycle, ed. R.W. Butler, Channel View Publications, Clevedon-Buffalo-Toronto 2006. 
Lundtrop S., Wanhill S., The Resort Lifecycle Theory. Generating Processes and Estimation, "Annals of Tourism Research" 2001, No. 28 (4).

Lundtorp S., Wanhill S., Time Path Analysis and TALC Stage Demarcation, in: The Tourism Area Life Cycle, ed. R.W. Butler, Vol. 2, "Conceptual and theoretical issues", Chanel View Publications, Clevedon-Buffalo-Toronto 2006.

Malisz B., Metoda analizy progowej w zastosowaniu do planowania miast i regionów, in: Metoda analizy progowej, eds. B. Malisz, J. Żurkowski, Studia KPZK PAN, Warszawa 1971, No. 34.

Miedziński M., Rozwój przestrzenny uzdrowiska Kołobrzeg od 1830 do 2009 roku oraz przemiany jego bazy noclegowej w latach 1989-2009, in: W trosce o przyszłość kołobrzeskiego uzdrowiska-międzynarodowe forum uzdrowiskowe, ed. E. Wiśniewski, Regionalne Stowarzyszenie Turystyczno-Uzdrowiskowe, Kołobrzeg 2009, Wydawnictwo. INTRO-DRUK, Koszalin 2009.

Miedziński M., Miasto Kołobrzeg wiodacym uzdrowiskiem Polski i jednym z centrów turystycznych kraju, in: Ekonomiczne i organizacyjne aspekty funkcjonowania polskich uzdrowisk, ed. E. Rydz, Wydawnictwo Akademii Pomorskiej, Słupsk 2012.

Miedziński M., Modyfikacja cyku życia obszaru turystycznego (TALC) w wyniku wprowadzenia założeń teorii progowej na bazie przestrzeni turystycznej Kołobrzegu i jego zaplecza, in: Współczesne problemy rozwoju turystyki w ujęciu regionalnym i lokalnym, eds. R. Jaroszewska-Brudnicka, D. Sokołowski, UMK Toruń, Toruń 2013.

Oppermann M., What is New With the Resort Cycle? Comment, "Tourism Management" 1998, Vol. 19.

Szromek A.R., Cykliczność rozwoju uzdrowisk na przykładzie uzdrowisk polskich, in: Uzdrowiska i ich znaczenie w gospodarce turystycznej, ed. A.R. Szromek, Proksenia, Kraków 2010.

\section{TWORZENIE MODELU PROGOWEGO CYKLU ŻYCIA OBSZARU TURYSTYCZNEGO NA PRZYKŁADZIE MIEJSKIEGO OBSZARU FUNKCJONALNEGO KOŁOBRZEG}

SŁOWA KLUCZOWE

STRESZCZENIE
Kołobrzeg, miejski obszar funkcjonalny, teoria progowa, cykl życia obszaru turystycznego, progowy cykl życia obszaru turystycznego

Opracowanie stanowi próbę kolejnej modyfikacji cyklu życia obszaru turystycznego (TALC) stworzonego przez R.W. Butlera. Do zmodyfikowanego TALC autor wprowadza założenia Teorii Progowej B. Malisza bazując na badaniach Kozłowskiego. Efektem tych działań jest stworzenie modelu progowego cyklu życia obszaru turystycznego (TTALC). Model teoretyczny oraz jego przebieg został następnie przetestowany na bazie FUA Kołobrzeg nazywanego Nadmorskim Obszarem Funkcjonalnym Kołobrzeg. Jest to jeden z najlepiej rozwiniętych tego typu regionów turystycznych Polski a do potwierdzenia jego progowego rozwoju użyto stwierdzonych przekroczeń progów rozwojowych popartych rozwojem infrastruktury technicznej, bazy noclegowej oraz ilości i wielkości powierzchni użytkowej substancji mieszkaniowej także w formie II domów i mieszkań. Podsumowaniem opracowania jest testowanie TTALC na przykładzie wybranych miejscowości turystycznych wchodzących w skład FUA Kołobrzeg w tym miasta - uzdrowiska Kołobrzeg. 